\title{
TAX COMPETITION AND IP BOXES AFTER THE APPLICATION OF THE MODIFIED NEXUS APPROACH
}

- Vit Jedlicka

\begin{abstract}
This article deals with intellectual property (IP) boxes as an important factor in tax competition and tax planning. IP payments are used for profit shifting within a group of companies to lower their tax burden. One of the latest important developments in the use of IP boxes is the changing attitude of the OECD and its nexus approach, the application of which influences taxation within an IP box, especially the treatment of expenditures. This paper focuses on the situation regarding IP boxes after the implementation of the modified nexus approach, with an emphasis on changing the tax burden. These changes affect tax planning, thus managers need to know how they affect the overall tax burden of a company's investments. As a measure of these changes, the effective average tax rate (EATR) was selected. This study concentrates on three countries which have applied this approach: Hungary, the Netherlands and the United Kingdom. The results indicate that there is a new dependence after the application of the modified nexus approach: the structure of IP expenditures. The implementation of nexus approach makes the statutory income tax rate important also for IP income, and it causes a higher tax burden on IP income in the case of a small share of IP qualifying expenditures. A significant importance of the statutory corporate tax rate for the taxation of IP income is shown by changes in EATRs related to IP income after a reduction in corporate tax rates in Hungary and in the United Kingdom in 2017.
\end{abstract}

Keywords: tax planning, IP box, modified nexus approach, tax competition, effective average tax rate JEL Classification: H25, M29

Received: December, 2017

1st Revision: October, 2018

Accepted: October, 2018

\section{INTRODUCTION}

At the present time corporate taxation ranks among one of the most important issues in management. Managers usually tend to reduce tax liabilities and to use the savings in every available way. When it comes to multinational companies, they use international tax planning to avoid paying taxes. International tax planning includes many different activities aimed at using the tax legislation of different countries to reduce tax costs. A network of established subsidiaries is the key prerequisite for the successful use of tax laws. 
Tax legislation within various countries provides managers with several ways to optimize tax liabilities, with one of the most common but also one of the newer methods being tax avoidance through IP boxes. The essence of this system is that revenues from IP (e.g. royalties for the use of a patent) are taxed in a separate box. Naturally, this brings some advantages for companies investing in IP. Typically, this benefit is represented by the possibility of lower rates. The actual situation of tax legislation in Europe reveals how important this solution to tax competition is, as all countries considered as a tax haven have their own IP box in force. Notable countries with the innovation box are Belgium, Hungary, the Netherlands, the United Kingdom and Luxembourg. One of the last countries to have implemented the principles of an IP box is Ireland (Deloitte, 2017). Tax burden within IP boxes is more important than the statutory corporate tax rate for groups with intangible assets. When the company produces e.g. patents, by their relocation the firm can easily lower the effective tax rate of the whole group.

As for other tax planning activities, international organizations have reacted to the use of IP boxes. The attitude of OECD shows how significant tax avoiding has become with IP boxes, since the organization had formed legislation which countries must follow when they have applied an IP box. The policy of the OECD is represented by the nexus approach, which countries apply in a modified form (OECD, 2015). These regulations have a significant impact on tax planning activities, therefore, it is important to analyze these legislation changes. Since the nexus approach is a new feature of IP boxes, research focus should shift into the taxation of IP income taking into account the new design of IP boxes. From the perspective of manager decision-making, this requires calculation, a condition which shows the effects of the nexus approach to the tax burden.

The goal of this paper is to determine how the modified nexus approach affects tax burden on IP income. The definition of the issue by a literature review is followed by a description of the methods used within this study. The fourth chapter is dedicated to the results, which then are further discussed together with conclusions and ideas for further research.

\section{THEORETICAL BACKGROUND}

Although IP boxes are novel strategies by governments, the relation between taxation and the location and knowledge of assets has been researched for several years. One study by Karkinsky \& Riedel (2009) focuses on the relationship between taxation and the location of patents. Their findings show that subsidiaries of multinationals apply for less patent applications when the corporate tax rate is high. Based on these results, the researchers claim that multinational companies tend to shift profits to countries with lower tax rates (Karkinsky \& Riedel, 2009). Nowadays, these findings are confirmed by the establishment of numerous IP boxes across the European Union.

One of the EU studies has also mentioned payments for intellectual property as a frequent instrument by which corporations avoid paying taxes (European Commission, 2016). The implementation of IP boxes creates more space for this type of tax planning activities. The importance of patent boxes in tax planning confirms another study by the European Commission in which Barrios et al. (2015) cooperated. Their study is focused on the effects of patent box on activi- 
ties of companies with their analysis providing several important findings. First, patent boxes, respectively the tax advantages, which patent boxes provide, attract multinationals to change the locations of their patents, especially when it comes to high-quality patents. Second, broadly conceived patent boxes with the possibility of including more types of rights affect patent location decisions even more. On the other hand, patent boxes do not increase research activities and multinationals use them mainly for tax planning purposes (Barrios et al., 2015).

Another study which deals with relations between tax planning and patents is from Bieltvedt Skeie et al. (2017), whose findings show that taxation is an important factor for setting the location of research activities. Lower taxation created by the implementation of an IP box attracts companies to concentrate their research and innovation activities in countries with such a regime. Further, a reduction in tax rate for IP income by 5 percentage points results in a $6 \%$ higher level of patents (Bieltvedt Skeie et al., 2017). Thus, these regimes concentrate patents, yet there is a question whether these IP boxes stimulate research activities. Similar results have been presented in a study by Bradley et al. (2015).

Griffith et al. (2014) mention one important aspect of intellectual property and its relation to tax planning: the fact that intellectual property shows the greatest mobility in a set of assets. Mobility as an important factor in terms of tax planning is also mentioned by Arcalean (2017) and Bretschger \& Hettish (2002). This mobility is the key factor for tax planning because multinationals can easily and quickly move these assets to another country where the legislation enables them to have lower effective tax rate. Tax savings from profit shifting is also connected with innovation activities according to results of a study by Klassen et al. (2017). Research by Griffith et al. (2014) shows how taxes and other factors are influential regarding where companies locate their intellectual property assets. This model shows that corporate tax is an important factor when it comes to the location of patents. For patent boxes, this means that they can actually persuade companies to change their locations of patents because of the lower effective tax rates for this part of their income (Griffith et al., 2014). From the perspective of different types of intangible assets, Dudar \& Voget (2016) show that the relocation of trademarks are based on tax planning to an even greater degree than such activity connected with patents.

Tab. 1 - Literature review related to the tax planning and IP. Source: author's own

\begin{tabular}{|l|l|l|}
\hline Authors and Year & Methods & Findings \\
\hline Karkinsky and Riedel (2009) & $\begin{array}{l}\text { Fixed effects OLS Random } \\
\text { effects tobit model Fixed } \\
\text { effects negative binomial } \\
\text { regression model }\end{array}$ & $\begin{array}{l}\text { Patents are applied in coun- } \\
\text { tries with a lower tax burden. }\end{array}$ \\
\hline Griffith et al. (2014) & Mixed logit model & $\begin{array}{l}\text { Choosing location of patents } \\
\text { is affected by patent boxes } \\
\text { (or a lower taxation). }\end{array}$ \\
\hline Evers et al. (2015) & $\begin{array}{l}\text { Effective average tax rate Ef- } \\
\text { fective marginal tax rate }\end{array}$ & $\begin{array}{l}\text { Presence of IP boxes de- } \\
\text { creases significantly effective } \\
\text { tax rates (in some cases even } \\
\text { to negative values). }\end{array}$ \\
\hline
\end{tabular}




\begin{tabular}{|c|c|c|}
\hline Chatagny et al. (2015) & $\begin{array}{l}\text { Computable general equilib- } \\
\text { rium model }\end{array}$ & $\begin{array}{l}\text { Swiss companies do not } \\
\text { change location of patents } \\
\text { because of the existence } \\
\text { of patent box in the home } \\
\text { country. }\end{array}$ \\
\hline Barrios et al. (2015) & $\begin{array}{l}\text { Negative binomial logit } \\
\text { Negative binomial-mixed } \\
\text { logit }\end{array}$ & $\begin{array}{l}\text { Lower tax burden of patent } \\
\text { boxes attracts companies } \\
\text { when they decide about loca- } \\
\text { tion of IP. }\end{array}$ \\
\hline Bradley et al. (2015) & Fixed effects panel regression & $\begin{array}{l}\text { Reduction in the tax rate for } \\
\text { IP income (within an IP box) } \\
\text { causes more patent applica- } \\
\text { tions. }\end{array}$ \\
\hline Stimmelmayr et al. (2016) & $\begin{array}{l}\text { Difference-in-difference } \\
\text { model }\end{array}$ & $\begin{array}{l}\text { Subsidiaries from groups } \\
\text { with IP have higher profits } \\
\text { after applying IP box than } \\
\text { the companies from groups } \\
\text { without IP. }\end{array}$ \\
\hline Bieltvedt Skeie et al. (2017) & $\begin{array}{l}\text { Negative binomial regression } \\
\text { model }\end{array}$ & $\begin{array}{l}\text { Patens are located in coun- } \\
\text { tries with a lower taxation. }\end{array}$ \\
\hline Mohnen et al. (2017) & $\begin{array}{l}\text { Difference-in-differences } \\
\text { method }\end{array}$ & $\begin{array}{l}\text { Dutch companies report } \\
\text { more R\&D activities when } \\
\text { they use the innovation box. }\end{array}$ \\
\hline Bornemann et al. (2018) & $\begin{array}{l}\text { OLS regression with panel } \\
\text { data }\end{array}$ & $\begin{array}{l}\text { Patent box in Belgium causes } \\
\text { higher R\&D activities and } \\
\text { companies achieve lower ef- } \\
\text { fective tax rates. }\end{array}$ \\
\hline
\end{tabular}

Other studies focus on a particular IP box within a certain country; Chatagny et al. (2015) in Switzerland, Mohnen et al. (2016) in the Netherlands as well as Bornemann et al. (2018) in Belgium. Chatagny et al. (2015) deal with the effects of the IP license box, which was part of Swiss tax reform. These results show that the license box dissuades companies from shifting profits outside of Switzerland. On the other hand, the researchers recognize only a partial effect of this IP box on output and on investments (Chatagny et al., 2015).

A study by Mohnen et al. (2017) covers the patent box implemented in the Netherlands. Here, companies using a patent box in the Netherlands tend to show more innovative activities because of the innovation box (Mohnen et al., 2017). The Dutch economy as a whole, however, shows no positive significant impacts from this. Overall, according to the studies from Switzerland and from the Netherlands, innovation boxes do not significantly affect a country's economy. There is a positive effect on monitored quantities (output or investments) but not a significant one. Although patent boxes (featuring a lower tax burden) attract companies to increase their innovation, the quality of these activities is lower than before the introduction of this regime (Schwab \& Todtenhaupt, 2017). 
On the other hand, Bornemann et al. (2018) show that not only patent activity is higher in Belgium after the application of the IP box, but also the effective tax rates of Belgian companies have decreased. This reduction is connected with companies which do not use profit shifting activities. There is no significant effect for multinationals with a developed tax planning scheme because they are able to reduce their tax burden without using the patent box in Belgium.

For companies, it is important to quantify the advantages for them and their budget. Managers want to reduce tax costs by using an IP box and this sort of analysis can be performed by monitoring effective tax rates (Evers et al., 2015). The IP box is incorporated into the formula for an effective average tax rate (EATR) developed by Devereux and Griffith $(1998,2003)$. The results show a significant effect on the tax burden of companies, an effect which is demonstrated by a reduction in the effective tax rate (Evers et al., 2015). All IP boxes provide better taxation conditions than in countries without the implementation of an IP box. One of the key findings here is the fact that there are significant differences between types of IP boxes, as the ones with no need to recapture expenditures can provide negative EATRs (Evers et al., 2015). This means that it is also important to follow up on every assessment of the effect of IP boxes, since fundamental differences can emerge with a large effect on the effective tax rate.

The activities of international organizations document the importance of IP boxes for international tax planning (OECD, 2017; European Commission, 2016). OECD (2017) focuses on IP boxes in one of their actions within the BEPS (Base Erosion and Profit Shifting) package. Because OECD sets these actions against harmful tax competition, its goal is to make legislation related to IP boxes transparent and focused on R\&D activities (OECD, 2015). OECD has agreed on the nexus approach to the IP box, which alters the IP boxes to provide benefits to companies only with real innovation activities and not to ones with artificial activities within tax planning (OECD, 2015). This approach has had an effect on tax legislation related to IP boxes and countries must apply the same changes to follow this agreement. Briefly, the modified nexus approach means that sum of IP expenditures, which has the character of outsourcing to related companies or IP acquisition (does not matter if a provider belongs to the company's group or not), affects the income taxable within the IP box.

Some papers also focused initially on the nexus approach as an important feature of IP box legislation, for example a study by Sanz-Goméz (2015), who focuses on IP boxes and the nexus approach in relation with EU laws. Sanz-Goméz mentions a problem regarding freedom with regard to several aspects of the nexus approach, e.g. with the treatment of expenditures considered as outsourcing. On the one hand, the nexus approach can cause harmful tax competition by the same treatment of expenditures in different countries; on the other, it raises several issues related to respecting the principles of EU legislation. Another study dealing with the nexus approach shows that the integration of the nexus approach tends to lower profit shifting activities (Stimmelmayr et al., 2016).

\section{RESEARCH OBJECTIVE, METHODOLOGY AND DATA}

The reviewed studies show that IP boxes are one of the key legislative elements allowing tax avoidance, with companies featuring $R \& D$ activities using this preferential tax regime to de- 
crease their effective tax rates. Considering the nexus approach, the following research questions can be posed:

- How does this new measure affect the effective tax rate within taxation via IP box?

- Will there be a minor gap between the effective tax rates of different countries due to the nexus approach?

The nexus approach changes IP boxes in the way IP expenditures are judged. Thus, it is important to determine how their implementation affects the effective tax rate, as IP boxes are mainly about tax avoiding. OECD as an international organization makes their own policy after discussion between member countries. This policy creates new regulations which member countries adopt into their legislation, so there is an assumption that IP boxes might remain similar. As mentioned earlier, for companies it is important to determine how much the effective tax rates of IP boxes differ after this legislative change.

The application of this OECD approach is a rather new feature of the legislation, with the first countries introducing it in 2016. Therefore, no relevant data are available as yet from companies. The identification of an influence by this application can be analyzed by a specific model for calculating the effective tax rate, with a popular method to measure effective tax burden being the formula for determining the effective average tax rate (EATR) by Devereux \& Griffith (2003). This model has the character of a "forward-looking measure", with the metric based on a situation of "bypothetical potential investment" (Devereux \& Griffith, 2003). The essence of this model lies in the calculation of the difference between net present value (NPV) assuming taxation and NPV in the situation without taxation (Devereux \& Griffith, 2003). The measure of the EATR has the following formula:

$$
\text { EATR }=\frac{R^{*}-R}{\frac{p}{1+r}}
$$

where $R^{*}$ is NPV of the investment when there is no taxation; $R$ is NPV assuming taxation; $p$ stands for real financial return and $r$ the real interest rate. For the present article, formula 1 is important as the main measure of effective tax burden. The calculation of NPVs $\left(R^{*}\right.$ and $\left.R\right)$ is presented below.

This model has been modified for taxation via IP box by Evers (2015), who makes several changes in the calculations owing to his different approach focused on taxation of IP. Evers (2015) has used this model assuming that income as the subject of taxation is generated by the "self-developed patent" financed by equity. For this situation, NPV with the presence of taxes is as follows:

$$
R=-(1-A)+\frac{(p+\delta)(1+\pi)}{1+i}\left(1-\tau_{I P B o x}\right)+\frac{(1-\delta)(1+\pi)}{1+i}(1-A)
$$

In formula 2: A stands for NPV of tax allowances; $\delta$ represents the economic depreciation rate; $\pi$ is inflation and $\tau_{\text {IP Box }}$ reflects profit tax rate related to IP income and $i$ is nominal interest rate.

The country's legislation determines the way how the NPV of tax allowance calculation is calculated. For Hungary, $\mathrm{A}$ is substituted by corporate tax rate $(A=\tau)$ because there is no recapture requirement of expenditures related to IP income (Evers, 2015). For the United Kingdom, it 
assumes "an investment project that is undertaken after the IP box regime was first opted for." (Evers, 2015) NPV of tax allowance (A) is set up $\tau_{\text {IP Box. }}$. Dutch legislation requires that IP expenditures have to be recaptured with mechanism based on threshold. For this mechanism, Evers (2015) has selected the same substitution as for the UK patent box $\left(A=\tau_{\text {IP Box }}\right)$.

One more formula from Devereux \& Griffith (2003) model is needed to calculate EATR of IP box regimes. This formula 3 calculates the NPV of the investment with no taxation. This value is the same for all selected countries:

$$
R^{*}=\frac{p-r}{1+r}
$$

Whereas the article deals with the modified nexus approach, there arises one problem related to calculation of EATR: how the nexus approach affects the calculation. First, there must be stated which part of Deveraux \& Griffith model is influenced by the nexus approach. To solve this problem, there helps formula 4 from OECD (2015), which represents the nexus approach itself:

$$
I P \text { Box income }=\frac{\text { Qualifying IP expenditures }}{\text { Overall IP expenditures }} * \text { Overall IP income }
$$

There can be applicable an uplift of qualifying expenditures by $30 \%$ (OECD, 2015), which is an important attribute of legislation. When there is not much outsourcing within the group and it corresponds to a small part of IP expenses, there is no effect of this approach on IP box income. The formula indicates that the application of the nexus approach affects the income, which can be included in IP box. This can also affects the tax rate, by which IP income is taxed because part of the income can be taxed as standard income by corporate income tax rate in some cases. As the IP box brings better taxation conditions, this nexus ratio can increase tax burden in some cases. Acquisition costs and expenditures for activities undertaken by related parties are not qualifying IP expenditures and their share affects real tax rate connected with IP income.

To include of the modified nexus approach into the model, there is important to mention that $\tau_{\text {IP }}$ Box cannot be put into equation in every possible situation. Several formulas have to be stated for calculating tax rates of IP income. There has to be modified this tax rate in case of a higher share of outsourced activities within the group or IP asset purchase. For the purposes of this article, there has been a new variable set, which substitutes $\tau$ IP Box in all occurrences in the previous equations: $\tau_{\mathrm{NA}}$ which stands for the tax rate after the application of the nexus approach.

Two basic types of patent box determine an approach to the tax rate after the application of nexus approach $\left(\tau_{\mathrm{NA}}\right)$. Patent box like the Dutch one with a tax rate for IP income stated in the legislation means that the whole IP income can be taxed by this tax rate. A condition, under which this tax rate is applicable to the whole income, is set by the nexus approach. For the Dutch like IP box, the formula for calculating a tax liability considering the nexus approach is as follows:

$$
T A X=\tau_{I P B O X} \frac{1,3 Q E I_{I P}}{T E}+\tau\left(P_{i p}-\frac{1,3 Q E I_{I P}}{T E}\right)
$$

QE stands for qualifying expenditures on IP asset; TE for total expenditures on IP asset and $I_{I P}$ for profit from IP asset. Formula 5 is applicable under the condition: $(1,3, Q E) / T E \leq 1,1$ is entered in the case of higher value. There can be applied only a limited uplift of qualifying expenditures 
with a maximum at the level of TE.

After mathematic operations, the formula for the tax rate after the application of nexus approach is the following:

$$
\tau_{N A}=\left[\frac{1,3 Q E}{T E}\left(\tau_{I P B o x}-\tau\right)\right]+\tau
$$

Formula 6 is adopted for the tax rate in the Netherlands and the United Kingdom. Whereas the study focuses on the effects of the nexus approach, for better detection of these, one key important assumption has to be stated: a situation only in the first interval of progressive taxation is assessed. For the Netherlands, it means that the corporate tax rate is $20 \%$, respectively it is assumed an income lower than EUR 200,000. The current corporate tax rate in the United Kingdom is at the level of $19 \%$.

For the second type of an IP box (for Hungary), the formula has to be formulated in a different way. There is no statutory specific tax rate because IP box has basic principle in a partial tax deduction. Formula 7 for tax liability in Hungary:

$$
T A X=\tau\left(I_{I P}-\frac{1,3 Q E I_{I P}}{T E}\right)+\left[\tau(1-d)\left(\frac{1,3 Q E I_{I P}}{T E}\right)\right]
$$

In the previous formula, $d$ is rate of the tax deduction. The condition mentioned with formula 5 stays unchanged.

The formula for the tax rate after the application of the nexus approach with the tax deduction is also different:

$$
\tau_{N A}=\left[\tau\left(1-\frac{1,3 Q E}{T E}\right)\right]+\left[\tau(1-d)\left(\frac{1,3 Q E}{T E}\right)\right]
$$

All the above mentioned formulas are used to calculate results in the following chapter.

The data used within these calculations are based on the legislation of selected countries and on the study from Evers (2015). Using the same assumptions as in the previous study allows for a more complex comparison of results, following which the differences in EATRs after the implementation of the nexus approach into IP boxes can be demonstrated.

Tab. 2 - Basic features of IP boxes in selected countries. Source: (Deloitte, 2017); (Koka et al. 2016); (Government Digital Services, 2015); (PWC, 2016); (KPMG, 2017)

\begin{tabular}{|l|l|l|l|}
\hline Country & Benefit & Assets & Corporate tax rate \\
\hline Hungary & $50 \%$ tax deduction & $\begin{array}{l}\text { Patents and software } \\
\text { copyrights }\end{array}$ & $9 \%(19 \%$ in 2016) \\
\hline $\begin{array}{l}\text { Nether- } \\
\text { lands }\end{array}$ & Tax rate at 5\% & $\begin{array}{l}\text { Patents, utility models, } \\
\text { plant breeders' rights, } \\
\text { and pharmaceutical } \\
\text { certifications }\end{array}$ & $\begin{array}{l}20 \% \text { up to EUR 200,000 } \\
(\text { above } 25 \%)\end{array}$ \\
\hline
\end{tabular}




\begin{tabular}{|l|l|l|l|}
\hline $\begin{array}{l}\text { United } \\
\text { Kingdom }\end{array}$ & Tax rate at $10 \%$ & Patents & $19 \%(20 \%$ in 2016) \\
\hline
\end{tabular}

Differences between IP boxes can be found in several areas of taxation. The first important feature is outlined in the methods used. The profitability of an IP box is indicated not only by the tax rate but also other special advantages, which can differ from one country to another. One of the key attributes is the provision by which profits can be included within this special regime. Thus, when it comes to a comparison of IP boxes, exactly which profits a company generates becomes important. Statutory corporate tax rates are not important for countries with the deduction system only but also for calculation with the application of the nexus approach, the results of which are mentioned in the following table. A basic comparison of IP boxes in selected countries is shown in Table 2.

The present article is focused on the quantitative characteristics of IP boxes. Therefore, it is important to calculate tax rates within IP boxes with the application of the nexus approach and, then, EATRs for selected cases which differ from each other by the proportion of qualifying expenses. For a better comparison of the results with the values of EATRs before the application of the nexus approach, the same assumptions have been selected as were in the study by Evers (2015): $\mathrm{p}$ (real financial return) is $20 \%, \mathrm{r}$ (real interest rate) is $5 \%, \delta$ (the economic depreciation rate) is $15.35 \%, \pi$ (inflation rate) has value of $2 \%$ and $\mathrm{i}$ (nominal interest rate) is $7.1 \%$.

\section{RESULTS AND DISCUSSION}

The comparison of IP boxes and EATRs after the application of the nexus approach in late 2016 is shown in the following graph - Figure 1. Selected countries did not implement any other changes beside the nexus approach in taxation related to IP income in 2016 (for example, Belgium adopted a different level of deduction). Thus monitors the situation in the second half of 2016.

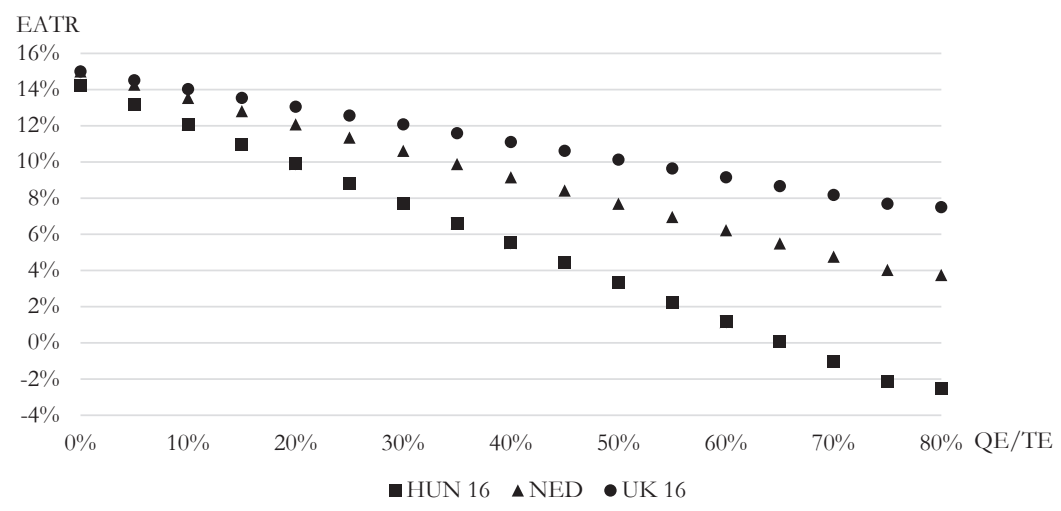

Fig. 1 - EATR dependence on the structure of IP expenditures in late 2016. Source: author's own data 
The dependence of an EATR on the structure of IP expenditures has a linear character in all countries because of the nexus approach, of which implementation has to be the same in all countries. On the other hand, this dependence has a different degree in every country. For the degree of dependence, the two following factors are important: specific calculation of the EATR caused by different types of IP boxes, and statutory corporate tax rate. The strongest dependency of the EATR was found in Hungary and this is caused by the fact that there is no recapture requirement for expenditures. For a large share of qualifying expenses, Hungary's EATR even drops to negative values. A different degree of dependency in the Netherlands and the United Kingdom creates a differential of 5 percentage points in the IP box tax rate because of the statutory corporate tax rate, which was at the same level of $20 \%$ in 2016.

The application of OECD causes the tax burden to rise below a $77 \%$ share of qualifying expenditures. The EATR has the same value for every possible structure of expenditures above the share of $77 \%$. Detailed values for a selected share of qualifying expenditures are shown in Table 3, as well as the values of EATRs for 2017.

The comparison of the results to the values from Evers (2015) can show how much the EATRs have changed after the application of the nexus approach. In 2014, the tax rate of an IP box was applicable for the entire IP income when all legislative conditions were met. With the adoption of the nexus approach, part of IP income is taxed by the statutory corporate tax rate in certain cases. The EATRs for the self-developed patent financed by equity were at the level of $-2.54 \%$ (Hungary), 3.75\% (the Netherlands) and 7.50\% (the United Kingdom) (Evers, 2015). These values remain unchanged after the application of the nexus approach for at least a $77 \%$ share of qualifying expenditures. Below this share, The EATRs increase up to the tax burden of regular corporate taxation, with a bigger gap related to a smaller share of qualifying expenditures. For $50 \%$ of qualifying expenses, the EATR increased by 5.88 percentage points in Hungary, by 3.94 percentage points in the Netherlands and by 2.63 percentage points in the United Kingdom. The nexus approach has had the biggest impact on the EATR in Hungary, the country with the best conditions for IP income among the selected countries. This comparison answers the first research question, i.e. the tax burden is indeed higher than before in the case of a low level of qualifying expenditures.

Tab. 3 - EATRs in selected countries after the application of the nexus approach. Source: author's own data

\begin{tabular}{|l|l|l|l|l|l|}
\hline \multirow{2}{*}{$\%$ QE } & \multicolumn{2}{|c|}{ Hungary } & Netherlands & \multicolumn{2}{c|}{ United Kingdom } \\
\cline { 2 - 6 } & 2016 & 2017 & Since 2016 & 2016 & 2017 \\
\hline 80 & -2.54 & -1.20 & 3.75 & 7.50 & 7.50 \\
\hline 75 & -2.12 & -1.00 & 4.03 & 7.69 & 7.67 \\
\hline 50 & 3.34 & 1.58 & 7.69 & 10.13 & 9.86 \\
\hline 25 & 8.79 & 4.17 & 11.34 & 12.56 & 12.06 \\
\hline 0 & 14.25 & 6.75 & 15.00 & 15.00 & 14.25 \\
\hline
\end{tabular}

When compared with the results of Evers (2015), Figure 1 and Table 3 also show that the gap between EATRs in different countries was smaller after the application of the nexus approach 
in 2016. For a small share of qualifying expenditures, the effective tax rates are nearly the same according to the results presented in Table 3. In these cases, the effects of different IP boxes are smaller than the effect of a relatively similar corporate tax rate (valid for the year 2016). This represents the second important result of the present study, as with the nexus approach the tax burden is lower in different countries in some cases. When the company does not conduct its own research activities, the IP income is taxed by the regular corporate tax rate and when they are similar (in 2016) the tax burden is relatively low.

The situation became even more interesting in 2017 when the government of Hungary and the United Kingdom decreased the statutory corporate tax rate. Nowadays, the corporate income tax rate is at the level of 9\% in Hungary and at 19\% in the United Kingdom. This reduction has had various effects in the selected countries. In Hungary, the EATR for greater share of qualifying expenditures increases to $-1.20 \%$. The tax burden on IP income has increased with the NPV calculation. The NPV of tax allowances (A) was lower than in 2016 because a lower corporate tax rate does not provide such a benefit in the case of taxation within the IP box. On the other hand, a different structure of expenses from the nexus approach perspective can lead to a lower EATR. In these cases, part of income is taxed by reduced corporate tax rate and a lower statutory corporate tax rate has a larger impact than a change in NPV of tax allowances, e.g. at a 50\% share of qualifying expenditures. The above mentioned effects cannot be applied to the United Kingdom, where the reduction of the statutory corporate tax rate has had an impact on the calculation of $\tau$ NA only. This affects the EATR only in the case of a lower smaller share than $77 \%$ of qualifying expenditures.

The implementation of the modified nexus approach brings a dependence of the EATR on the structure of expenditures. Overall, the formula for the tax rate with the application of the modified nexus approach brings a new variable which can be called a share of the company's own expenditure regarding the development of an IP asset. The effects of this approach on companies will be dependent on the corporations' flexibility to convert the structure of expenditures. Thus a new important activity can be related to managing IP.

The above mentioned dependence has a negative character, and a lower share of qualifying expenditures increases the EATR. Whereas the qualifying expenditures do not include outsourcing activities within the group nor IP acquisition, it disadvantages mainly tax planning activities within the group, which is, after all, the purpose of the nexus approach. On the other hand, it can also negatively affect companies who do not have their own resources. These companies must use know-how from the parent company or buy IP assets from third parties, and this increases their tax burden. Overall, the advantage of a preferential tax regime for IP income is lower in the case of many outsourced activities within the group or with IP acquisitions.

The results also show that the modified nexus approach makes the corporate income tax rate for IP income more important. Previously, the advantage of an IP box had been applicable to the whole qualified income. Nowadays, the part of IP profit which does not meet the conditions of the modified nexus approach is taxed with the corporate tax rate. This change increases the effective tax rates for IP income and this difference is even bigger in countries with a higher corporate tax rate. The results after the reduction of the corporate tax rate in Hungary and in the United Kingdom are notable, as similar legislative changes have had different effects because of the type of IP box. 
In this case, OECD regulation creates similar effective tax rates in the selected countries (in a situation of a lower share of qualifying expenditures). The modified nexus approach results in more space for tax planning activities since there is a new manageable variable affecting EATRs. On the one hand, it makes profit shifting activities less attractive due to the treatment of payments within the group. On the other, this profit shifting can be replaced by relocating R\&D activities and then it does not affect the EATR for the future. Capital mobility is an important factor related to the tax planning a factor which is demonstrated by recent studies (Arcalean, 2017; Bretschger \& Hettish, 2002).

The comparison of IP boxes (more precisely effective tax rates within IP boxes) is relatively complicated because the nexus approach has different impacts on each of them depending on the type of IP box in a particular country. Treatment of income, the construction of taxation, and other factors are important and related to how the nexus approach works. Moreover, the nexus approach also has different effects after changes of the other related tax legislation, in studying cases, statutory corporate tax rates. For these reasons, results cannot be specified for the nexus approach as one measure, differences among IP boxes should also be considered as key factors of these changes. This study has also a limitation in regards to a forward-looking EATR. This method provides the first information about the nexus approach and its effect on effective tax rates. On the other hand, further studies should use real economic data from companies (e.g. company databases) to analyze real effects of the nexus approach implementation.

The results of this study show the significant impact of the nexus approach on effective tax rates in some cases but only the analysis of the companies' dataset reveals how frequent these effects are and how many groups are hurt from this OECD requirement. Therefore, one question arises in regard to further research into IP boxes after this study: how much the modified nexus approach affects real corporate tax liabilities. Then, two issues can be quantified: whether the different treatment of the expenditures mentioned affects significantly real effective tax rates, and if managers are able to avoid paying taxes despite the application of this legislation, for example by using the above-mentioned capital mobility. The importance of IP activities in tax planning is shown by several studies and by the modified nexus approach, as one of the main policies of OECD related to IP boxes creates new challenges in the tax planning activities for managers. As international organizations play an important role in assessment of the tax planning, further studies have to take into account other changes coming from OECD or EU.

\section{CONCLUSION}

This article shows how a small change in legislation can greatly affect tax burden. IP payments are a popular way for groups can shift their profits to avoid paying taxes. Therefore, this new regulation is even more important for managers. This is the reason why the nexus approach is a crucial tool for companies. IP boxes are used for tax planning and by influencing the effective tax rate the nexus approach can lower the advantages from these special tax regimes.

Firstly, this paper shows that the nexus approach increases the tax burden in cases of when a low level of qualifying expenditures by a company are allocated. This regulation does not influence companies with their own research activities, since it has no effect on EATR with a high level 
of qualifying expenditures. On the other hand, this new regulation affects not only companies which purposefully outsourced IP activities within their own group, but also companies without their own resources. These companies buy IP assets from third parties when they are active in IP activities. In the case of $50 \%$ of qualifying expenditures after the application of the nexus approach, the EATR increased by 5.88 percentage points for Hungary, 3.94 for Netherlands, and 2.63 for the United Kingdom. Interestingly, some governments have reduced statutory corporate tax rates after the application of the new regulation, notably Hungary and the United Kingdom. The IP box increases the value of the EATR for a high level of qualifying expenditures in Hungary. Companies with their own research activities have worse taxation conditions than used to be the case. However, it is worth mentioning that this reduction of corporate tax rate is not the direct impact of the nexus approach.

For the second research question, the nexus approach moves the EATR values closer for the companies using IP boxes for tax planning or those not having their own research activities. On the other hand, this new measure has no effect on the tax burden when the company has a high share of its own real expenditures, for example on new patents. Significant differences remain in these cases and the IP box, e.g. in Hungary, is more advantageous than in the two other countries. Similar values in some cases are caused not so much by a difference in corporate tax rates, but the reduction of rates in Hungary creates a specific position for this country, as its taxation seems to be the lowest among the selected countries.

Overall, managers face a new problem consisting of controlling the IP expenditure structure. Another important aspect which is currently important for IP boxes is the level of the corporate income tax rate, which is relatively high in some countries. Nowadays, the benefits of the IP box come not only by directly connected legislation but also the statutory corporate tax rate and the structure of company's IP expenditures. The modified nexus approach creates a situation in which IP boxes are in some cases less attractive. Tax planning activities become more complicated, but there is no potential to stop activities completely. Only the ways companies avoid paying taxes will be different. Whereas the patents and other intangible assets have a high mobility and real innovative activity can be easily relocated, managers should also consider location changes of R\&D to obtain tax advantages and to lower group's effective tax rate.

\section{References}

1. Arcalean, C. (2017). International tax competition and the deficit bias. Economic Inquiry, 55 (1), 51-72. https://doi.org/10.1111/ecin.12358

2. Barrios, S., Alstadsæter, A., Nicodème, G., Skonieczna, A. M., \& Vezzani, A. (2015). Patent boxes design, patents location and local R\&D. Luxembourg: Office for Official Publications of the European Communities.

3. Bieltvedt Skeie, Ø., Menon, C., Johansson, A., \& Sorbe, S. (2017). Innovation, patent location and tax planning by multinationals. OECD Economics Department Working Papers. https://doi.org/10.1787/b08459e5-en

4. Bornemann, T., Laplante, S. K., \& Osswald, B. (2018). The Effect of Intellectual Property Boxes on Innovative Activity \& Effective Tax Rates. WU International Taxation Research Paper Series, No. 2018-03. https://doi.org/10.2139/ssm.3115977 
5. Bradley, S., Dauchy, E. P., \& Robinson, L. (2015). Cross-Country Evidence on the Preliminary Effects of Patent Box Regimes on Patent Activity and Ownership. Tuck School of Business Working Paper No. 2681433. https://doi.org/10.2139/ssrn.2681433

6. Bretschger, L., \& Hettich, F. (2002). Globalisation, Capital Mobility and Tax Competition: Theory and Evidence for OECD Countries. European journal of political economy, 18 (4), 695-716. https://doi.org/10.1016/s0176-2680(02)00115-5

7. Chatagny, F., Koethenbuerger, M., \& Stimmelmayr, M. (2015). Introducing an IP Licence Box in Switzerland. KOF Working Papers, 390. https://doi.org/10.3929/ethz-a-010483173

8. Deloitte (2017). 2017 Survey of Global Investment and Innovation Incentives.

9. Devereux, M. P., \& Griffith, R. (2003). Evaluating tax policy for location decisions. International Tax and Public Finance, 10 (2), 107-126. https://doi.org/10.1023/a:1023364421914

10. Devereux, M., \& Griffith, R. (1998). The taxation of discrete investment choices. IFS Working Papers, No. W98/16, Institute for Fiscal Studies (IFS), London. https://doi. org/10.1920/wp.ifs.1998.9816

11. Dudar, O., \& Voget, J. (2016). Corporate taxation and location of intangible assets: Patents vs. trademarks. ZEW Discussion Papers, No. 16-015. https://doi.org/10.2139/ssrn.2753656

12. European Commission. (2016). The Impact of Tax Planning on Forward-Looking Effective Tax Rates. Luxembourg: Publications Office of the European Union.

13. Evers, L. (2015). Intellectual Property (IP) Box Regimes: Tax Planning, Effective Tax Burdens, and Tax Policy Options (Doctoral dissertation).

14. Evers, L., Miller, H., \& Spengel, C. (2015). Intellectual property box regimes: effective tax rates and tax policy considerations. International Tax and Public Finance, 22 (3), 502-530. https://doi.org/10.1007/s10797-014-9328-x

15. Government Digital Services (2015) Corporation Tax: Patent Box - compliance with new international rules. [online] gov.uk. Retrieved 16.06.2017 from https://www.gov.uk/ government/publications/corporation-tax-patent-box-compliance-with-new-internationalrules/corporation-tax-patent-box-compliance-with-new-international-rules

16. Griffith, R., Miller, H., \& O'Connell, M. (2014). Ownership of intellectual property and corporate taxation. Journal of Public Economics, 112, 12-23.

17. Karkinsky, T., \& Riedel, N. (2009). Corporate taxation and the choice of patent location within multinational firms. CESifo Working Paper, No. 2879.

18. Klassen, K. J., Lisowsky, P., \& Mescall, D. (2017). Transfer pricing: Strategies, practices, and tax minimization. Contemporary Accounting Research, 34 (1), 455-493. https://doi. org/10.1111/1911-3846.12239

19. Koka, G., \& Kocsis, G. (2016) New IP regime in Hungary. [online] expertguides.com. Retrieved 16.06.2017 from https://www.expertguides.com/articles/new-ip-regime-inhungary/arrgbfql

20. KPMG. (2017). Corporate tax rate table. [online] kpmg.com. Retrieved 16.06.2017 from https://home.kpmg.com/xx/en/home/services/tax/tax-tools-and-resources/tax-ratesonline/corporate-tax-rates-table.html 
21. Mohnen, P., Vankan, A., \& Verspagen, B. (2017). Evaluating the innovation box tax policy instrument in the Netherlands, 2007-13. Oxford Review of Economic Policy, 33 (1), 141-156. https://doi.org/10.1093/oxrep/grw038

22. OECD. (2015). Countering Harmful Tax Practices More Effectively, Taking into Account Transparency and Substance, Action 5 - 2015 Final Report, OECD/G20 Base Erosion and Profit Shifting Project. Paris: OECD Publishing.

23. OECD. (2017). BEPS Action 5 on Harmful Tax Practices - Terms of Reference and Methodology for the Conduct of the Peer Reviews of the Action 5 Transparency Framework, OECD/G20 Base Erosion and Profit Shifting Project. Paris: OECD.

24. PWC. (2016). International Tax News, Edition 42, August 2016. [online] pwc.com. Retrieved 16.06.2017 from https://www.pwc.com/gx/en/tax/newsletters/international-tax-services/ assets/pwc-international-tax-news-august-2016.pdf

25. Sanz Gomez, R. (2015). The OECD's Nexus Approach to IP Boxes: A European Union Law Perspective. WU International Taxation Research Paper Series. No. 2015-12.

26. Schwab, T., \& Todtenhaupt, M. (2017). Spillover from the Haven: Cross-border Effects of Patent Box Regimes within Multinational Firms.

27. Stimmelmayr, M., Koethenbuerger, M., \& Liberini, F. (2016). Is it Luring Innovations or just Profit? The Case of European Patent Boxes. Beiträge zur Jahrestagung des Vereins für Socialpolitik 2016: Demographischer Wandel - Session: Innovation and the Global Economy, No. A03-V1, ZBW - Deutsche Zentralbibliothek für Wirtschaftswissenschaften, Leibniz-Informationszentrum Wirtschaft, Kiel und Hamburg.

\section{Contact information}

Ing. Vit Jedlickea

University of Pardubice

Faculty of Economics and Administration

Department of Business Economics and Management

Cqech Republic

E-mail:vit.jedlicka@upce.cr. 